\title{
Evaluation of the Effectiveness of Employment Programmes on Young Unemployed People
}

\section{Laura Juznik Rotar}

University of Novo mesto, Faculty of Economics and Informatics

Na Loko 2, 8000 Novo mesto, Slovenia

E-mail.laura.juznik-rotar@uni-nm.si

cross $^{\text {ref }}$ http://dx.doi.org/10.5755/j01.ee.32.1.23276

Youth unemployment is of paramount concern for the European Union. Young people are facing potentially slow and difficult transitions into stable jobs. What optimally supports young people on the labour market poses a challenging question for economic policy makers. Active labour market policies can be beneficial to young unemployed people. The aim of active labour market policy is to improve employability of the unemployed. The consequences of an overly generous welfare state can be a reduction in motivation to work. The effectiveness of employment programmes is therefore a crucial step in the process. This paper aims to estimate the treatment effect of subsidized employment programmes on young Dutch unemployed people using difference in differences propensity score matching. We test whether the effects of subsidized employment programmes for young Dutch unemployed people are positive and strong in both the short and long term on the probability of re-employment and on the probability of participation in the regular educational system in comparison with the outcome produced in the event that an individual would continue seeking employment as an unemployed person. The probability of reemployment in short-term circumstances is positive, but small. Whereas with long-term examples (two years after the programme start) the probability is negative. Alternatively, the probability of participation in regular educational systems is positive in the short-term as well as in the long-term, but evidently decreases in the long-term. Welfare reforms undertaken in the Netherlands are directed towards enhancing efficiency. The role of social partners in social security administrations is reduced and the reforms are intended to promote reintegration of people who are out of work. There is a general agreement that the Netherlands is going in the right direction by giving priority to work and study over benefits, as it has become evident that generous social benefits make employment policies inefficient.

Keywords: Active Labour Market Policy; Dutch Labour Market; Young People; Youth Unemployment; Employment Programme; Effectiveness; Treatment Effect; Propensity Score Matching with Difference in Differences.

\section{Introduction}

Youth unemployment is usually more sensitive to fluctuations in the business cycle compared to the unemployment of older people. According to data by Eurostat, the unemployment rate for people under the age of 25 is approximately $17 \%$ (EU28). One of the top priorities of the European Union according to their 2020 strategy is to reduce youth unemployment. Youths are faced with low chances of finding work, their jobs tend to be less stable and significant skills are mismatched on the labour market.

An active labour market policy is key when tackling youth unemployment and social exclusion as it contributes to an increase in employment and a decrease in unemployment. Since there are large funds intended for the active labour market policy, and there is increasing pressure in terms of budget limitations, an ageing population and other challenges, the question of effectiveness of employment programmes is appropriate. There is need for external programme evaluation. This paper aims to fill this gap.

Many of the programmes targeted towards youth (especially those who have high risk) have revealed disappointing outcomes. Not only are the programmes not suitable to the needs of unemployed youths (for example, based on the same type of schooling and lacking practical working experiences), with poorly defined objectives to meet, but also rigorous activation strategies that may discourage such disadvantaged groups of youths unemployed to register at the Centre for Work and Income (CWI) which has a central role in providing social assistance. They have a high risk of staying in the margin and not going back to school as well as tackling illegal and shadow economy activities (Jakstiene et al., 2013).

The Dutch labour market performance (the research leading to these results has received funding from the European Union) reveals there is a high fraction of longterm unemployed workers and low average working hours due to high part-time work among workers (Gautier \& Van Der Klaauw, 2009; OECD, 2015). Youth unemployment is usually higher than the average unemployment due to annual influx of school leavers, the fact that young people are usually working on the basis of a temporary contract, they have less firm specific knowledge and they are more sensitive to cyclical movements (see, for example Ciegis et al., 2013; Marjanovic \& Mihajlovic, 2014). Part of the youth unemployment is caused by the mismatch on the labour market.

Because the situation for the young people on the labour market is different nowadays, they face with a risk of ending in vicious circle of temporary unskilled jobs, unemployment and programmes (Juznik Rotar, 2012, 
2019). Novak et al. (2016), on the other hand, also highlight that generous welfare state, high taxation and other labour market rigidities can reduce motivation on the labour market.

Youth unemployment in the Netherlands has increased in recent years. According to the Eurostat data the unemployment below the age of 25 reached its peak in 2013 at 13,2 \%, numerous are also school dropouts. In particular, the point of concern is high unemployment among young people without basic educational qualifications. Between 2008-2014, youth unemployment for ISCED levels 0-2 (less than primary, primary and lower secondary education) in the Netherlands increased more than 10 percentage points before decreasing to 12,3 $\%$ in 2017. Youth long-term unemployment has increased from $0,5 \%$ in 2008 to $2,3 \%$ in 2014 and by 2017 still did not reach its level before economic crisis. An important indication of Dutch youth labour market performance is the NEET rate which has increased in recent years, reaching a peak of $4,0 \%$ in 2013.

The objective of empirical research is to identify the causal effect of employment programmes (subsidized employment) on the probability of re-employment and on the probability of participation in the regular educational system of young unemployed Dutch people. This is approached by using difference in differences propensity score matching. Since the main aim of the active labour market policy is to improve employability of the unemployed, the outcome measure probability of reemployment is the natural measure of successfulness for employment programmes (see, for example Berzinskiene \& Juozaitiene, 2011). The second outcome measure we use in empirical research is the probability of participation in the regular educational system. This outcome measure reflects the current situation on the labour market, as well as the characteristics of young people as vital and dynamic labour market segments that are more vulnerable to fluctuations in business cycle and often finds further participation in the regular educational system as a solution to currently unfavourable conditions on the labour market.

As part of the research we check whether the effects of employment programmes (subsidized employment) for young unemployed Dutch people are positive and strong in the short, as well as in the long-term, on the probability of re-employment. This also applies to the probability of participation in the regular educational system in comparison with the outcome produced in the event that an individual would continue seeking employment as an unemployed person.

\section{Literature Review}

In the Netherlands, there are two organizations responsible for benefit administration. The nationwide public insurance administration is responsible for unemployment insurance and disability insurance benefits. Whereas the social services departments of the municipalities administer the welfare recipients. There has also been a change in provision of active labour market programmes, meaning that nationwide public insurance administration and municipalities do not offer active labour market programmes, but instead contract commercial agencies. This should strengthen competition between commercial agencies and result in better active labour market programmes and more efficient use of resources (see, for example Broersma et al., 2013; Kluve et al., 2007). One problem is high diversification of active labour market programmes in structure and content. Each commercial agency offers different programmes, as well as most evaluation research being done by commercial agencies, whereas such evaluations suffer from lack of suitable econometric skills for programme evaluation based on modern econometrics techniques (OECD, 2008, 2016). We focus our literature review with regards to the objective stated.

Estimations of treatment effects of employment programmes using modern propensity score matching analysis have been applied in different studies (see, for example Abdennadher \& Sahnoun, 2018; Lechner \& Wunsch, 2009; Vikstrom, 2017). Lombardi et al. (2017) using Swedish administrative data show in their study that treated firms can benefit from targeted wage subsidies. Positive effects were evident before the introduction of reform in 2007, which removed the participation of workers in subsidy process. Whereas Van Ours (2004) report potential decreasing job search efforts of young unemployed people participating in subsidized employment in the short-term, this is the so-called lock-in effect. The duration of unemployment periods is key for future labour market prospects of youth. Schmillen \& Umkehrer (2017) confirm that young people faced with early stages of unemployment in their career have worse employment prospects in future. Moreover, Stefanik et al. (2018) found positive treatment effects of participating in supporting workplace programmes for young unemployed graduates, but negative income effects.

Kaiser \& Kuhn (2016) studied the worker-level and firm-level effects of a wage subsidy programme for highly educated workers using propensity score matching. Kaiser \& Kuhn (2016) found that wage subsidy programmes had positive effects on employment and annual earnings during the participation in these programmes, while there were no positive effects once the programme ended. While Kaiser \& Kuhn (2016) confirmed statistically significant effects for the number of highly educated employees during the programme participation, as well as after the programme had ended, this was not true for the total number of employees where effects were found only during the programme participation.

Using a matching approach, Scott-Clayton \& Minaya (2016) examined the effects of student employment subsidies on academic and employment outcomes. For those programme participants who would have worked even in the absence of the subsidy programme, the programme reduced hours worked and improved academic outcomes while there was little effect on post-college employment. The effects were contrary for those students who would not have worked otherwise.

Caliendo \& Schmidl (2016) examined youth unemployment and active labour market policies in Europe and provided comprehensive survey on the effectiveness of these active labour market policies for youth in Europe. With respect to employment outcomes and taking into account wage subsidy programmes, Caliendo \& Schmidl 
(2016) found that there were more mixed effects for wage subsidy programmes. Whereas Card et al. (2010) found that wage subsidy programmes were often ineffective, whilst Kluve (2010) used meta-analysis and reported effectiveness of wage subsidies in increasing participants' employment probability. Caliendo \& Schmidl (2016) stressed the high likelihood of unemployment for youth after the wage subsidy expired and another problem of worker substitution. Kluve \& Schmidt (2002) studied the employment subsidies for which the effects on employment outcome were heterogeneous and wrote that young unemployed people are difficult to assist.

Whereas, Carling \& Larsson (2005) found no evidence of the measure to prevent long-term youth unemployment by guaranteeing an assignment to some labour market programme within 100 days of unemployment. This point suggests that early intervention was neither helpful nor important for young unemployed people. Further unemployment experience for long-term youth unemployed school-leavers significantly decreased chances of finding employment (Cockx \& Picchio, 2013). Similar conclusions based on a wide range of counterfactual impact evaluations of youth employment programmes can be found in Kluve et al. (2016). The type of intervention was less decisive, especially with regards to high-income countries. Alternatively, the programmes that integrated multiple interventions provided evidence on labour market outcomes due to better responses to different needs of beneficiaries.

\section{Methodology}

Data

We obtained data for this research via research project funded by the European Union. In this empirical research we use microdatasets on labour and social security provided by the Central Bureau of Statistics Netherlands (CBS). The objective of this paper is to evaluate the effectiveness of employment programmes on young unemployed people, whereas we focused on subsidized employment programmes for youth aged 20-24 for the year 2008 due to the availability of data and high diversification of employment programmes in the Netherlands. Our data vector consists of dummy variables land of birth indicating 1 the Netherlands and 0 otherwise; variable number of parents abroad indicating 1 at least one parent living abroad and 0 none; variable generation indicating 1 autochthonous inhabitants and 0 otherwise; numerical variable age measured in years; variable sex indicating 1 men and 0 women; employment status before the programme indicating 1 employed and 0 otherwise and numerical variable unemployment duration before the programme measured in days. Descriptive statistics of variables included in the empirical research is presented in Table 1 .

Table 1

\section{Descriptive Statistics}

\begin{tabular}{|l|c|c|}
\hline \multicolumn{1}{|c|}{ Variable } & Mean & Std. dev. \\
\hline Land of birth & 0,66 & 0,47 \\
\hline Number of parents abroad & 0,48 & 0,49 \\
\hline Generation & 0,41 & 0,07 \\
\hline Age & 20,91 & 0,58 \\
\hline Sex & 0,56 & 0,49 \\
\hline Employment status before the programme & 0,42 & 186,03 \\
\hline $\begin{array}{l}\text { Unemployment duration before the } \\
\text { programme }\end{array}$ & 130,85 & 1,49 \\
\hline
\end{tabular}

Source: Own calculations; CBS Data.

Obtained research results are then connected with the current position of young unemployed Dutch people with respect to outcome measures used in the research. Subsidized employment is one of the main types of active labour market policy. Together with activation strategies they are designed to promote labour market integration by reducing job-finding obstacles and increasing the probability of re-employment. Subsidies are designed to compensate for lack of work experience and other deficits (Eichhorst \& Rinne, 2014). The Dutch government introduced a measure where employers who employ young persons who are entitled to benefit will receive a premium discount $(3.500$ EUR per year) with a maximum of two years. From a financial point of view, employers are thus more motivated to employ young people (Dutch initiatives to prevent and tackle youth unemployment). However, Kluve et al. (2007) conclude that only subsidized employment in private sectors have a positive effect on employment in a sense of outflow from these jobs into ordinary jobs.

From available datasets we formed two groups of data: an experimental group and potential control group. The experimental group is represented by young unemployed people aged between 20-24 who after registering with the Employment Service in 2008 enrolled in a subsidized employment programme. The experimental group consists of more than 200 observations. Whereas, the potential control group is represented by young unemployed people aged 20-24, who registered with the Employment Service in the year 2008 and never participated in any of the programmes. We have to be cautious with this latter group since unemployment periods before the start of the programme is important when explaining the selection into a programme. We followed the subsequent procedure suggested by Lechner (1999). We divided both groups by the month of registration with the Employment Service as unemployed. The data for the length of pre-programme unemployment was randomly distributed to observations from the potential control group based on such data of observations in the experimental group. If an actual unemployment period of an observation in potential control group was shorter than the randomly distributed one, the observation was removed from the sample. 


\section{Method}

A convenient framework for defining causal quantities and deriving corresponding estimators is offered by Rubin's causal model with its potential outcomes notation (see, for example Heckman \& Pinto, 2015). Formal framework of the Rubin causal model says that each individual $i$ has two potential outcomes a) the potential control outcome $\mathrm{Y}_{\mathrm{i}}{ }^{0}$ under the control condition $\left(\mathrm{D}_{\mathrm{i}}=0\right)$ and $\left.\mathrm{b}\right)$ the potential treatment outcome $\mathrm{Y}_{\mathrm{i}}{ }^{1}$ under treatment condition $\left(\mathrm{D}_{\mathrm{i}}=1\right)$. Where $\mathrm{Y}_{\mathrm{i}}^{1}$ and $\mathrm{Y}_{\mathrm{i}}^{0}$ are called potential outcomes since they are unknown but fixed outcomes before individual $i$ gets assigned or selects into the treatment or control condition. Only one of the two potential outcomes is revealed after treatment, that is the potential treatment outcome for the treated and the potential control outcome for the untreated. The respective other potential outcomes remain hidden. Since in practice for the same individual $i$ we never observe both potential outcomes simultaneously, this represents the main hindrance for modelling the causality (Heckman \& Pinto, 2015). The estimator is unbiased if an ignorable selection mechanism is established via randomization. But, in practice randomization is frequently not possible due to practical, ethical or other reasons so that researchers have to rely on observational studies (see, for example Huber et al., 2018). Following the framework of Rubin causal model the difference in differences matching estimator is implemented by calculating the propensity score on the baseline year. Difference in differences propensity score matching method is a contemporary method and commonly used method of empirical analysis for evaluating treatment effects, proposed by the literature in the field of evaluating programmes (Morris et al., 2013; Rubin, 2005). The method mentioned enables better decision-making based on the quantification of the effects of employment programme. Matching methods try to match treated and control individuals on observed characteristics in order to create comparable groups just as it would have been done by randomization. The comparison group must be statistically equivalent to the treated group, meaning that the groups must be identical except that one of them received treatment (see, for example Abadie \& Imbens, 2016; Austin \& Stuart, 2017; Lechner \& Wunsch, 2013). Such circumstances allow the counterfactual outcome for the treated group to be inferred and therefore for any differences between the treated and untreated to be attributed to the treatment. This means that untreated individuals are used to construct counterfactual for the treated group (see, for example Huber et al., 2013; Lechner \& Strittmatter, 2017). Difference in differences estimator allows for unobserved heterogeneity that may lead to selection bias, but assumes that this unobserved heterogeneity is constant over time (Crespi et al., 2011). Propensity scores can be used to match treated and control individuals having rich dataset before-and-after the programme intervention. Treatment effect is calculated across treated and matched control individuals within the common support (Khandker et al., 2010).

First we carry out probit estimation to determine how variables: land of birth, number of parents abroad, generation, age, sex, employment status before the programme, unemployment duration before the programme influence the participation probability in the employment (subsidy) programme. Table 2 displays the probit regression model of the likelihood of participation in the programme.

Table 2

Propensity Score Coefficient Estimates

\begin{tabular}{|l|c|c|}
\hline \multicolumn{1}{|c|}{ Variable } & Coefficient & St. error \\
\hline Land of birth & $-0,2845$ & 0,1722 \\
\hline Number of parents abroad & $-0,1176$ & 0,1387 \\
\hline Generation & $0,2749^{*}$ & 0,1255 \\
\hline Age & $-0,1981$ & 0,6153 \\
\hline Sex & $-0,1433^{*}$ & 0,0702 \\
\hline Employment status before the programme & $-0,7939^{*}$ & 0,0683 \\
\hline Unemployment duration before the programme & $0,0104^{*}$ & 0,0009 \\
\hline Constant & 1,2162 & 6,5104 \\
\hline
\end{tabular}

Notes: * Denotes significance at the $5 \%$ level.

Source: Own calculations; CBS Data.

Conditional independence assumption, which is one of the conditions to prove validity of propensity score matching, is not a directly testable assumption. Therefore, it has to be justified by data quality as found in the literature (see, for example Heinrich et al., 2010; Khandker et al., 2010). We use data obtained via research project funded by the European Union, whereas the Central Bureau of Statistics Netherlands provided rich microdatasets on labour and social security (CBS, 2012). Additionally, we have a sample of more than 700 eligible non-participants in comparison to the sample of 200 participants that also enables us to facilitate better matching. According to this information, we consider the conditional independence assumption holds.
Common support is another condition for the validity of propensity score matching which can be tested. It implies that for each value of $\mathrm{X}$ there is a positive probability of being both treated and untreated. This condition of common support ensures that there is a sufficient overlap in the characteristics of treated and untreated units to find adequate matches (Rosenbaum and Rubin, 1983). Figure 1 shows the density distribution of propensity score (histogram) in groups of participants and in groups of non-participants. Based on Figure 1, we see that for the great number of participants there are similar non-participants, so we conclude that the common support is satisfied. Only 1,1\% of individuals have been discarded in the estimations (Becker \& Ichino, 2002). 


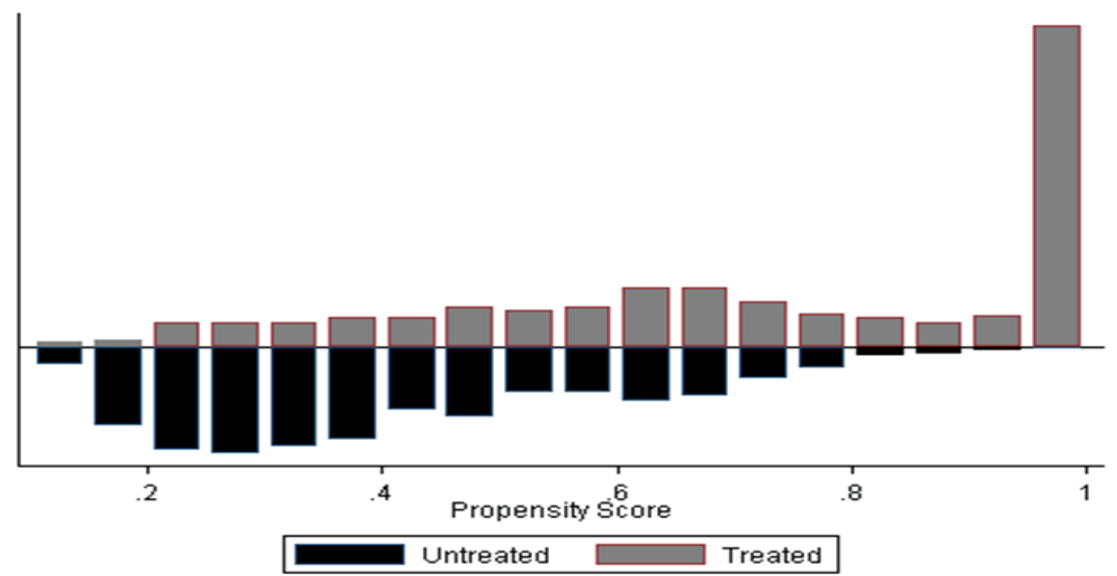

Figure 1. Distribution of Estimated Propensity Score by Treatment Status Source: Own calculations; CBS Data

The next step we performed was to analyse the quality of the matching between treated and non-treated individuals. We follow Rosenbaum and Rubin (1983) who suggest checking whether significant differences between average values of the variables for both groups exist after matching. According to Heinrich et al. (2010) eliminating the differences should increase likelihood of unbiased treatment effects. For the majority of variables in our case, matching helps reduce the bias associated with observable characteristics.

\section{Results}

Subsequently we realized propensity score matching in combination with difference in differences approach. We calculated average treatment effects on the treated ATT (see, Table 3) on the outcome variable re-employment probability and probability of regular studies one/two years after the programme starts. The outcome variables were generated as difference of re-employment probability of 2009 and 2007, additionally of 2010 and 2007, as well as difference of regular studies for the same years respectively.

Table 3

Average Treatment Effect on the Treated

\begin{tabular}{|c|c|c|c|c|c|}
\hline Variable & Sample & Treated & Controls & Difference & St. error \\
\hline \multicolumn{6}{|c|}{ One year after the programme start } \\
\hline \multirow{2}{*}{$\begin{array}{l}\text { Re-employment } \\
\text { probability }\end{array}$} & Unmatched & 0,280 & $-0,296$ & $0,576^{*}$ & 0,030 \\
\hline & ATT & 0,280 & 0,263 & 0,017 & 0,127 \\
\hline \multirow{2}{*}{$\begin{array}{l}\text { Probability of } \\
\text { regular studies }\end{array}$} & Unmatched & 0,016 & $-0,035$ & $0,051 *$ & 0,022 \\
\hline & ATT & 0,016 & $-0,039$ & 0,055 & 0,080 \\
\hline \multicolumn{6}{|c|}{ Two years after the programme start } \\
\hline \multirow{2}{*}{$\begin{array}{l}\text { Re-employment } \\
\text { probability }\end{array}$} & Unmatched & 0,135 & $-0,275$ & $0,410^{*}$ & 0,030 \\
\hline & ATT & 0,135 & 0,195 & $-0,060$ & 0,131 \\
\hline \multirow{2}{*}{$\begin{array}{l}\text { Probability of } \\
\text { regular studies }\end{array}$} & Unmatched & $-0,015$ & $-0,009$ & $-0,006$ & 0,022 \\
\hline & ATT & $-0,015$ & $-0,020$ & 0,005 & 0,085 \\
\hline \multirow{2}{*}{$\begin{array}{l}\text { ATT re- } \\
\text { employment } \\
\text { probability } 2007\end{array}$} & Unmatched & 0,268 & 0,645 & $-0,376^{*}$ & 0,021 \\
\hline & ATT & 0,268 & 0,184 & 0,084 & 0,093 \\
\hline \multirow{2}{*}{$\begin{array}{l}\text { ATT re- } \\
\text { employment } \\
\text { probability } 2009\end{array}$} & Unmatched & 0,548 & 0,349 & $0,199 *$ & 0,022 \\
\hline & ATT & 0,548 & 0,447 & 0,101 & 0,089 \\
\hline \multirow{2}{*}{$\begin{array}{l}\text { ATT re- } \\
\text { employment } \\
\text { probability } 2010\end{array}$} & Unmatched & 0,404 & 0,369 & $0,034 *$ & 0,022 \\
\hline & ATT & 0,404 & 0,379 & 0,024 & 0,089 \\
\hline \multirow{2}{*}{$\begin{array}{l}\text { ATT probability of } \\
\text { regular studies } 2007\end{array}$} & Unmatched & 0,173 & 0,121 & $0,052 *$ & 0,016 \\
\hline & ATT & 0,173 & 0,097 & 0,076 & 0,062 \\
\hline \multirow{2}{*}{$\begin{array}{l}\text { ATT probability of } \\
\text { regular studies } 2009\end{array}$} & Unmatched & 0,190 & 0,086 & $0,103^{*}$ & 0,016 \\
\hline & ATT & 0,190 & 0,058 & $0,131^{*}$ & 0,055 \\
\hline \multirow{2}{*}{$\begin{array}{l}\text { ATT probability of } \\
\text { regular studies } 2010\end{array}$} & Unmatched & 0,158 & 0,112 & $0,045^{*}$ & 0,016 \\
\hline & ATT & 0,158 & 0,076 & 0,081 & 0,061 \\
\hline
\end{tabular}

Notes: * Denotes significance at the $5 \%$ level.

Source: Own calculations; CBS Data. 
With the described approach we find an average treatment effect on the treated of $1,7 \%$ and $-6,0 \%$ for the outcome variable re-employment probability one/two years after the programme start respectively. One year after the programme start re-employment probability of participants is raised by $1,7 \%$ through the employment programme, whereas two years after the programme start the reemployment probability is decreased by $6,0 \%$ through the employment programme. On the other hand, one year after the programme start the probability of regular studies of participants is raised by $5,5 \%$ through the employment programme, whereas two years after the programme start the probability of regular studies is increased by $0,5 \%$ through the employment programme. Our results to some extent are similar to those presented in previous research (see, for example OECD, 2008). However, the estimated treatment effects cannot be generalized. The average treatment effect on the treated (ATT) is calculated as ATT=(afterbefore) $\left.)_{\text {treated-(after-before }}\right)_{\text {control. For the outcome variable re- }}$ employment probability one year after the programme start, for example, the ATT is calculated as $0,280-0,263=0,017$. Through the combination of matching and difference in differences we have eliminated the time constant unobserved effects. This can be seen if we calculate the ATT as the difference between ATT re-employment probability $2009(0,101)$ and ATT re-employment probability 2007 $(0,084)$. The same can be concluded for other outcome variables respectively.

\section{Discussion and Implications}

The positive treatment effect for outcome variable reemployment probability one year after the programme start is to some extent similar to those presented in previous research. This factor emphasizes that only subsidized employment in private sectors have a positive effect on employment in a sense of outflow from these jobs into ordinary jobs (nevertheless the database for our research do not enable us to detect whether employment took place in a private or public sector which is seen as a limitation of our research). However, this positive effect can also be attributed to how the Netherlands pursues the strategy of part-time flexible employment opportunities for young people. Gaining working experience and developing human capital as well as forming social networks can be seen as a path to permanent full-time contracts (Eichhorst \& Rinne, 2014). This is of high importance, especially for young migrants who are overrepresented among unemployed youth and can also be generalised based on descriptive statistics of our data. Following 2008, the unemployment rate of young people with non-western background in the Netherlands increased substantially and reached its peak in 2014 at 17,8 $\%$ as a consequence of economic situation. In the period mentioned, the unemployment rate for native young Dutch people has been consistently lower. The problem could be seen in the limited focus on vulnerable groups into which young migrants fall. The over-representation of young people with non-western background within the youth unemployed in the Netherlands could be due to their job search behaviour (intensity and effectiveness), limited network and discrimination. Furthermore due to their low educational background (see the data in the next paragraph) which limits their understanding of the available information regarding different schemes and employment programmes could be made more transparent and easy to understand. This could contribute to lowering administrative burdens and regulatory complexity and could facilitate efficient integration of young migrants. In spite of the trend of digitalisation of information and government services, the personalized approach and support towards young people with non-western background could help them optimize their integration into Dutch society.

However, in the long-term, the re-employment probability decreases and is even negative. One possible reason are the consequences of economic crisis on the labour market which come with the delay. Since the subsidized employment programme is primarily offered to disadvantaged unemployed people there is also risk that a potential employer sees participation in such programme as a negative signal (see, for example Stefanik, 2014). Another problem on the Dutch labour market is a high number of school dropouts. Young people leave education because of wrong study choice or the type of education offered (little or no connection with real workplaces). They often do not meet basic educational levels, do not have the pertinent skills or qualifications needed on the labour market and consequentially have weak positions on the labour market and are vulnerable to becoming unemployed. The situation described is evident for young people with non-western background. In 2016, $58 \%$ of young people with nonwestern background had basic educational qualifications. What is more, the proportion of early school leavers among young people with non-western background without basic educational qualifications is still higher than for native young Dutch people (CBS, 2017).

In the context of present and future labour demand in the Dutch labour market, the immigration policy plays an important role in light of development of strategic sectors in the Dutch economy and overall regional development of a country. The Dutch labour migration system was demanddriven migration until recently when they introduced supply-driven migration schemes where job offers are not a precondition and migrants may instead be admitted based on their characteristics (OECD, 2016). Such schemes were oriented towards international graduates from Dutch universities and expanded also towards graduates from recognized universities across the world.

The policy shift towards the recruitment and retention of skilled migrants and international graduates can be seen as an opportunity for young people with non-western background to improve their career developments and prospects for their future life.

Higher levels of education tend to reduce risks of unemployment and encourage a better sense of well-being and less pressure on social security expenditures (Giziene et al., 2012).

According to some major reforms, the Netherlands has been able to reduce the generosity of unemployment insurance and the number of benefit recipients. The philosophy of a 'work first approach' towards getting unemployed people back to work as soon as possible and 
limiting dependence on benefits, or at least reducing it to a minimum, was adopted (Van Schie, 2015; OECD, 2008).

An important implication for EU labour market decision makers is to consider some structural challenges young people face when entering a labour market. Starting with labour market segmentation, young people are overrepresented in temporary and part-time contracts, pushing young people into the risk of precarious employment, relatively low wages and bad long-term employment prospects usually as a result of tight employment protection legislation. To address such structural challenges, policy makers could utilize targeted subsidized schemes where subsidy is conditional on keeping young people in employment for some period after the end of subsidy. There should also be some balance between protection and rights of permanent and temporary employment contracts, as well as promoting entrepreneurship among young people and supporting them with necessary services and information that also promotes labour mobility. Another important structural challenge is the performance of education and training systems. These systems should be more oriented towards the needs of the labour market and provide high quality education that develop effective strategies for school dropouts and low skilled young people and also recognize informal and non-formal learning. The culmination of such obstacles when entering the labour market means that young people are also hindered by the availability of quality work experience, as well as a low capacity of public employment services to provide tailored services and support to young people in vulnerable situations. Therefore, the capacity of public employment services should be strengthened in order to provide personalized counselling and adequate support to young people based on their specific needs and profiles. Moreover, implementation of activation policies and sustainable integration of young people should be managed through efficient labour market institutions reaching the European 2020 employment target.

\section{Conclusions}

Despite the Dutch labour market's above average performance in comparison to other OECD countries, with youth unemployment rates below $10 \%$, the situation after the economic crisis has impacted young people the most. Therefore, an effective and active labour market policy targeted towards youths is essential, along with the developed institutions, to provide a smooth transition between school and work in order to prevent young people feeling stuck in temporary unskilled jobs, unemployment and programmes.

The orientation of active labour market policy towards promoting activation of unemployed and lowering social benefits should be promoted. It has become evident that generous social benefits make employment policies inefficient. It is important that the Netherlands continues with the package of some fundamental reforms (e.g. unemployment benefits that decrease with the duration of unemployment, employment protection that is less dependent on the length of the labour contract, less agedependent planning in collective labour bargaining). This point would contribute to the improvement of labour market positions of unemployed people and the position of young unemployed people of various backgrounds.

To provide regular and systematic monitoring and evaluation of active labour market programmes, the culture of evaluation should be promoted and suitable econometric skills for programme evaluation developed.

The orientation towards reducing the number of early school leavers and strengthening links between education and labour market is essential to helping young Dutch people. This principal is especially relevant for young people with non-western backgrounds and being able to offer them an effective start on the labour market. It is also important to raise the quality of education pertinent to the needs of the labour market and therefore prevent labour mismatch.

Given the significant number of young unemployed people, amongst which those of non-western background are overrepresented, the route of entrepreneurship as a means out of unemployment should be promoted. Young people benefit from entrepreneurial learning, developed business knowledge and essential competences and skills including: creativity, initiative, tenacity, teamwork, understanding of risk and a sense of responsibility. These are competences and skills that increase employability within young people.

Contrarily, the orientation of policy towards skilled migration and international graduates could be seen as an opportunity for young people of various backgrounds. This applies in particular to future prospects on the labour market and could be complemented with exchange programmes and visits as well as subsidized courses which would increase the understanding of Dutch language and culture.

\section{References}

Abadie, A., \& Imbens, G. W. (2016). Matching on the Estimated Propensity Score. Econometrica, 84(2), $781-807$. https://doi.org/10.3982/ECTA11293

Abdennadher, C., \& Sahnoun, M. (2018). The assessment of active labor market policies: evidence from OECD countries. Economia Politica, 35(2), 257-283. https://doi.org/10.1007/s40888-018-0102-X

Austin, P. C., \& Stuart, E. A. (2017). Estimating the Effect of Treatment on Binary Outcomes Using Full Matching on the Propensity Score. Statistical Methods in Medical Research, 26(6), 2505-2525. https://doi.org/10.1177/096228 $\underline{0215601134}$

Becker, S. O., \& Ichino, A. (2002). Estimation of Average Treatment Effects Based on Propensity Scores. The Stata Journal, 2(4), 358-377. https://doi.org/10.1177/1536867X0200200403 
Berzinskiene, D., \& Juozaitiene, L. (2011). Impact of Labour Market Measures on Unemployment. Inzinerine Ekonomika-Engineering Economics, 22(2), 186-195. https://doi.org/10.5755/j01.ee.23.2.1541

Broersma, L., Edzes, A. J. E., \& Van Dijk, J. (2013). Have Dutch Municipalities Become More Efficient in Managing the Costs of Social Assistance Dependency? Journal of Regional Science, 53(2), 274-291. https://doi.org/10.1111/ j.1467-9787.2012.00762.x

Caliendo, M., \& Schmidl, R. (2016). Youth unemployment and active labor market policies in Europe. IZA Journal of Labor Policy, 5(1), 1-30. https://doi.org/10.1186/s40173-016-0057-x

Card, D., Kluve, J., \& Weber, A. (2010). Active Labour Market Policy Evaluations: A Meta-Analysis. The Economic Journal, 120(548), F452-F477. https://doi.org/10.1111/j.1468-0297.2010.02387.x

Carling, K., \& Larsson, L. (2005). Does early intervention help the unemployed youth? Labour Economics, 12(3), 301319. https://doi.org/10.1016/j.labeco.2003.12.001

CBS (2012). Labour Market Policy Database. CBS: Den Haag/Heerlen.

CBS (2016). Annual Report on Integration 2016. CBS: Den Haag/Heerlen.

CBS (2017). Unemployment Down Among Non-western Migrant Group. Available from internet: https://www.cbs.nl/engb/news/2017/32/unemployment-down-among-non-western-migrant-group

Ciegis, R., Nakciunaite, E., \& Mikalauskiene, A. (2013). Dependence between Labour Market and Economic Cycles. Inzinerine Ekonomika-Engineering Economics, 24(4), 320-330. https://doi.org/10.5755/j01.ee.24.4.2898

Cockx, B., \& Picchio, M. (2013). Scarring effects of remaining unemployed for long-term unemployed school-leavers. Journal of the Royal Statistical Society: Series A (Statistics in Society), 176(4), 951-980. https://doi.org/10.1111/ j.1467-985X.2012.01086.X

Crespi, G., Maffioli, A., Mohnen, P., \& Vazquez, G. (2011). Evaluating the Impact of Science, Technology and Innovation Programs: a Methodological Toolkit. New York: IDB-Strategy Development Division.

Dutch initiatives to prevent and tackle youth unemployment. Available from internet: http://www.garanziagiovani.gov.it/ Documentazione/Documents/piano\%20di\%20implementazione\%20Paesi\%20Bassi.pdf

Eichhorst, W., \& Rinne, U. (2014). Promoting Youth Employment Through Activation Strategies. Employment Working Paper no 163. Geneva: ILO.

Giziene, V., Simanaviciene, Z., \& Palekiene, O. (2012). Evaluation of Investment in Human Capital Economical Effectiveness. Inzinerine Ekonomika-Engineering Economics, 23(2), 106-116. https://doi.org/10.5755/j01.ee.23.2. $\underline{1541}$

Gautier, P. A., \& Van Der Klaauw, B. (2009). Institutions and Labour Market Outcomes in the Netherlands. IFAU Working Paper 28. Uppsala: IFAU.

Heckman, J. J., \& Pinto, R. (2015). Causal Analysis After Haavelmo. Econometric Theory, 31(1), $115-151$. https://doi.org/10.1017/S026646661400022X

Heinrich, C., Maffioli, A., \& Vazquez, G. (2010). A Primer for Applying Propensity Score Matching. New York: IDBStrategy Development Division.

Huber, M., Lechner, M., \& Wunsch, C. (2013). The Performance of Estimators Based on the Propensity Score. Journal of Econometrics, 175(1), 1-21. https://doi.org/10.1016/j.jeconom.2012.11.006

Huber, M., Lechner, M., \& Strittmatter, A. (2018). Direct and Indirect Effects of Training Vouchers for the Unemployed. Journal of the Royal Statistical Society Series A, 181(2), 441-463. https://doi.org/10.1111/rssa.12279

Jakstiene, S., Purvinis, O., \& Susniene, D. (2013). Analysis of the Most Vulnerable Labour Market Segments During the Period of Economic Development in Lithuania. Inzinerine Ekonomika-Engineering Economics, 24(4), 331-342. https://doi.org/10.5755/j01.ee.24.4.2240

Juznik Rotar, L. (2012). How Effective Is the Slovenian Institutional Training Program in Improving Youth's Chances of Reemployment? Eastern European Economics, 50(3), 94-106. https://doi.org/10.2753/EEE0012-8775500305

Juznik Rotar, L. (2019). What are the Treatment Effects of a Work-First Participation Programme on Young Unemployed People in the Netherlands? Panoeconomicus, 66(2), 203-2017. https://doi.org/10.2298/PAN160714028J

Kaiser, U., \& Kuhn, J. M. (2016). Worker-level and firm-level effects of a wage subsidy program for highly educated labor: Evidence from Denmark. Research policy, 45(9), 1939-1943. https://doi.org/10.1016/j.respol.2016.05.008

Khandker, S. R., Koolwal, G. B., \& Samad, H. A. (2010). Handbook on Impact Evaluation. Quantitative Methods and Practices. Washington, D.C.: World Bank. https://doi.org/10.1596/978-0-8213-8028-4 
Kluve, J. (2010). The Effectiveness of European Active Labor Market Programs. Labour Economics, 17(6), 904-918. https://doi.org/10.1016/j.labeco.2010.02.004

Kluve, J., Card, D., Fertig, M., Gora, M., Jacobi, L., Jensen, P., Leetmaa, R., Nima, L., Patacchini, E., Schaffner, S., Schmidt, C. M., Van Der Klaauw, B., \& Weber, A. (2007). Active Labor Market Policies in Europe. Performance and Perspectives. Heidelberg: Springer-Verlag. https://doi.org/10.1007/978-3-540-48558-2

Kluve, J., Puerto, S., Robalino, D. A., Romero, J., Rother, F., Stoterau, J., Weidenkaff, F., \& Witte, M. (2016). Do Youth Employment Programs Improve Labor Market Outcomes? A Systematic Review. IZA Discusion Paper No. 10263.

Kluve, J., \& Schmidt, C. M. (2002). Can Training and Employment Subsidies Combat European Unemployment? Economic Policy, 17(35), 409-448. https://doi.org/10.1111/1468-0327.00093

Kubík, R. (2015). What is the Real Effect of Schooling on Economic Growth? Prague Economic Papers, 24(2), 125-135. https://doi.org/10.18267/j.pep.504

Lechner, M. (1999). Identification and Estimation of Causal Effects of Multiple Treatments Under the Conditional Independence Assumption. IZA Discussion Paper No. 91. Bonn: IZA. https://doi.org/10.2139/ssrn.177089

Lechner, M., \& Wunsch, C. (2009). Are Training Programs More Effective When Unemployment Is High? Journal of Labor Economics, 27(4), 653-692. https://doi.org/10.1086/644976

Lechner, M., \& Wunsch, C. (2013). Sensitivity of Matching-Based Program Evaluations to the Availability of Control Variables. Labour Economics, 21, 111-121. https://doi.org/10.1016/j.labeco.2013.01.004

Lechner, M., \& Strittmatter, A. (2017). Practical Procedures to Deal With Common Support Problems in Matching Estimation. Forthcoming in Econometric Reviews. https://doi.org/10.1080/07474938.2017.1318509

Lombardi, S., Nordstrom Skans, O., \&Vikstrom, J. (2017). Targeted wage subsidies and firm performance. Labour Economics, 53, 33-45. https://doi.org/10.1016/j.labeco.2018.04.002

Marjanovic, G., \& Mihajlovic, V. (2014). Analysis of Hysteresis in Unemployment Rates with Structural Breaks: the Case of Selected European Countries. Inzinerine Ekonomika-Engineering Economics, 25(4), 378-386. https://doi.org/10.5755/j01.ee.25.4.5263

Morris, S., Todtling-Schonhofer, H., \& Wiseman, M. (2013). Design and Commissioning of Counterfactual Impact Evaluations. Luxembourg: Publications Office of the European Union. https://doi.org/10.2767/94454

Novak, V., Vokoun, M., Stellner, F., \& Vochozkaet, M. (2016). Institutional Analysis of the Contemporary Regional Labour Market in the Czech Republic. E\&M Ekonomie a Management, 19(3), 4-19. https://doi.org/10.15240/ tul/001/2016-3-001

OECD (2016). Recruiting Immigrant Workers. The Netherlands. Paris: OECD. https://doi.org/10.1787/9789264259249-en

OECD (2015). Employment Outloook 2015. Paris: OECD. https://doi.org/10.1787/empl_outlook-2015-en

OECD (2008). Jobs for Youth. Netherlands. Paris: OECD. https://doi.org/10.1787/9789264041295-en;

Rosenbaum, P., \& Rubin, D. B. (1983). The Central Role of Propensity Score in Observational Studies for Causal Effects. Biometrika, 70(1), 41-55. https://doi.org/10.1093/biomet/70.1.41

Rubin, D. B. (2005). Causal Inference Using Potential Outcomes. Design, Modelling, Decisions. Journal of the American Statistical Association, 100(469), 322-331. https://doi.org/10.1198/016214504000001880

Schmillen, A., \& Umkehrer, M. (2017). The scars of youth: Effects of early-career unemployment on future unemployment experience. International Labour Review, 156(3/4), 465-494. https://doi.org/10.1111/ilr.12079

Scott-Clayton, J., \& Minaya, V. (2016). Should student employment be subsidized? Conditional counterfactuals and the outcomes of work-study participation. Economics of Education Review, 52(3), 1-18. https://doi.org/10.1016/ j.econedurev.2015.06.006

Stefanik, M. (2014). Estimating Treatment Effects of a Training Programme in Slovakia Using Propensity Score Matching. Ekonomicky casopis, 62(6), 631-645.

Stefanik, M., Karasova, K., \& Studena, I. (2018). Can supporting workplace insertions of unemployed recent graduates improve their long-term employability? Forthcoming in Empirica. https://doi.org/10.1007/s10663-018-9413-y

Van Schie, P. G. J. C. (2015). Dutch Self Fullfilling Social Experiments: the Solution for the Young and the Jobless? St. Dutch Foundation of Innovation Welfare 2 Work. Available from internet: http://www.way2learn2work.eu/ index.php/gb/home-gb/2-uncategorised/151-28-29-may-meeting-in-netherlands

Van Ours, J. C. (2004). The locking-in effect of subsidized jobs. Journal of Comparative Economics, 32(1), 37-55. 
https://doi.org/10.1016/j.jce.2003.10.002

Vikstrom, J. (2017). Dynamic treatment assignment and evaluation of active labor market policies. Labour Economics, 49, 42-54. https://doi.org/10.1016/j.labeco.2017.09.003

\section{Author's biography}

Laura Juznik Rotar is an Associate Professor of Economics at the Faculty of Economics and Informatics University of Novo mesto. She received her PhD degree from the Faculty of Economics, University of Ljubljana. She has published in refereed journals, such as Panoeconomicus, Eastern European Economics, Economic Research. She has been involved in several research projects on national and European level. Research field: labour economics, effectiveness of ALMP, youth unemployment, SME, decision models.

The article has been reviewed.

Received in April 2019; accepted in February 2021.

This article is an Open Access article distributed under the terms and conditions of the Creative Commons Attribution 4.0 (CC BY 4.0) License (http://creativecommons.org/licenses/by/4.0/). 